\title{
Information Technology roles in Accounting Tasks - A Multiple-case Study
}

\author{
Maria do Céu Gaspar Alves
}

\begin{abstract}
Nowadays the business world is changing at a faster and faster pace. The reasons given for this is globalization, highs information technology (IT) investments and the rapid pace of technological change. Organizations are responding in different ways and at different rates to the wide range of IT based opportunities and pressures. The purpose of this paper is to focus on the effects of IT related organizational changes on the management accounting function and to contribute to the body of knowledge about to what extent IT affects the ability to solve accounting tasks. The relationship between IT and accounting practices was investigated qualitatively using six case studies and we will measure the impact of IT on accountants' tasks. The findings suggest a tendency for change and the decentralization of accounting tasks.
\end{abstract}

Index Terms-Accounting, Accounting Information Systems, Financial Documents, Information Technology, Management Information System.

\section{INTRODUCTION}

Nowadays the business world is changing at a faster and faster pace. The reasons given for this is globalization, highs IT investments and the rapid pace of technological change in combination with escalating costs of research and development (Frishamar, 2002). The role of information technology (IT) has shifted over the last decades (Teng \& Calhoun, 1996) to become an important part of how companies manage and control their resources. Organizations are responding in different ways and at different rates to the wide range of IT based opportunities and pressures (Johnson et al., 1986). Decisions regarding the building of technical IT architecture should be closely linked to decisions made in designing the IT organisation that should be linked to the organisational design of the company itself. As a result, "Information technology plays a critical role in modern business, especially regarding the accounting function" (Efendi et al, 2006:117). IT have radically transformed the nature of business and accounting practice (Hunton, 2002). "The initial interest in the relationships between accounting and information technology was gradually taken for granted; accounting was simply not possible without information technology, and the assumption appears to be that information technology is the platform for accounting data and it allow certain sophisticated queries to be performed" (Granlund \& Mouritsen, 2003:78). Thus, IT and accounting systems would be a major component of accounting research. "While it is widely acknowledged that IT plays an important role (and increasingly so) in the field of accounting, the relationship between IT and accounting has been studied relatively little" (Granlund, 2007:3).

Based on a literature review of earlier research and empirical studies we conclude that there is a very limited knowledge about the impact of the most recent IT developments in the accounting field (Granlund, 2007). Although IT clearly plays an important role in accounting (Efendi et al., 2006) and management control (Dechow et al., 2007), this relationship has not been studied enough. Existing research has focused mostly on the relation between IT investment and company performance (Melville et al., 2004; Huang et al., 2006), notably in studies that attempt to measure the level of IT investment and company productivity (Dedrick et al., 2003) or even the financial return on IT investments (Dehning \& Richardson, 2002). But, empirical studies examining the relationship between IT and performance have reported mixed findings (Dedrick et al., 2003; Melville et al., 2004). As well as conflicting results suggest that there is no direct relationship between IT investments and firm performance (Yongmei et al., 2008). So, the relationship between IT and firm performance seems to be more complex than previously theorized (Stoel \& Muhanna, 2009).

The purpose of this paper is to focus specifically on the effects of IT related organizational changes on the management accounting function. We will seek to prepare the management accounting profession for the challenges which IT will pose, and to contribute to the body of knowledge about to what extent IT affects the ability to solve different accounting tasks. Hence, we will try to measure the impact of IT usage on accountant tasks.

\section{LITERATURE REVIEW}

The impact of modern information technologies in companies is broad and manifested in the most varied ways. Integrated systems, such as ERP systems, Internet, Intranet, and so on, walk hand in hand with the most recent developments in company know-how. Some of these technologies, with their widespread use, especially the Internet, have altered the way companies work and their accounting organization (Granlund, 2007). "Prior to the emergence of this environment, the presence of IT in the organization has typically taken the form of specific computer application systems, such as accounts payable and financial reporting systems, which either automate specific operational procedures or support certain managerial processes" (Teng \& Calhoun, 1996:674). It is usually argued that the first use of an information system was in relation to 
accounting (Rom \& Rohde, 2007), because often IT was about the firm's financial ledgers and reporting systems (Granlund \& Mouritsen, 2003). But, "the constantly growing and changing field of information technology has a significant impact on the roles of executives at all levels of business organizations" (Crescenzi \& Kocher, 1984:34). Nowadays research within management accounting and information systems is coming alive with the advent of integrated information systems such as enterprise resource planning (ERP) systems (Chien \& Tsaur, 2007). In this context,"information management has emerged as the most common brief name for the management of the use of information technology in an organization" (Frishamar, 2002:149).

The new information and communication technologies represent a vector of development and an important component of the formal information system is represented by computerised information. The possibilities for sharing and exchanging information among those involved may lead to informal cognitive networks, like electronic discussion boards, and can reinforce relationships with economic partners (idea and knowledge exchanges, for example). However, electronic information seems to continue to suffer from its abstract and artificial character and from the greater trust, often attributed to less impersonal communications (McLeod et al., 1984). And, it is unrealistic to think that an information system, whatever it may be, can always supply the decision maker with relevant and timely information. The decision maker would have to know in advance which information would be needed, when this type of prediction is, by definition, impossible within complex problem solving (Simon, 1945). Nevertheless, IT represents a precious assistance in the search for and treatment of information needed in the decision making process (Connor \& Martinsons, 2006).

Currently, the manner in which accountants can potentially add value to economic entities and society is undergoing a metamorphosis. Many traditional accounting tasks dealing with recording and processing of accounting transactions can be reliably automated. Thus, accountants add little incremental value to organizations in this regard anymore. Rather, an accountant's worth is now reflected in higher-order critical-thinking skills, such as designing business processes, developing e-business models, providing independent assurance, and integrating strategic knowledge (Hunton, 2002). Accordingly to Crescenzi and Kocher (1984) the rapid evolution of IT represents both an opportunity and a potential risk for the accountant. By avoiding the potential risk the accountants can use the new IT to enhance his role within the organization. Prior to the 1960s the accountant was perceived as a bookkeeper whose primary responsibility was ensuring that records were kept. The accountant fought a constant battle against the failure of record. During the 1960s the accountant was able to respond to manager's requests for reports on the business activities. Computers provided a more efficient means of keeping the books, and they afforded the accountant quick access to financial information for reporting purposes. Next, the 1970s brought both IT developments and manager's increase demand for more information about the business. Management information systems were developed to support the new accountant's role. However, the new management information systems generated all the information without regard to its relevance and the accountant was forced to become the interpreter of information (Crescenzi \& Kocher, 1984), and to deal with the problem of information overload. So we have a "paradoxical situation that, although there is an abundance of information available, it is often difficult to obtain useful, relevant information when it is needed" (Edmunds \& Morris, 2000:17).

Traditionally, research in Information Systems has focused on the study of information processing, on computer systems security and on the development of new systems; leaving for study the relationship between IT and accounting. Even those studies that have, in some way, covered this relationship fall short due to their focus on outdated tools. Also research on management accounting and integrated information systems has evolved across a number of different lines of research. Some place heavier emphasis on the management accounting side, while others emphasise the information systems side (Rom \& Rohde, 2007:41). Nonetheless, to be able to understand emerging technologies and anticipate their effects on accounting, we must begin to understand the effects of the most up-to-date technologies (Hopwood, 1987).

\section{EMPIRICAL STUDY}

Fundamental philosophical assumptions about the nature of reality, knowledge and human behaviour underlie any research and influence the researcher's notion of acceptable research methods (Chua 1986, Hopper \& Powell 1985). "In recent years, management accounting research conducted within the positivist and functionalist paradigms has shown increasing recognition of the need to complement established quantitative methods with a greater or lesser element of qualitative, case study-based research" (Modell, 2005:232). Calls for such a complementary approach, relying on method triangulation, combining elements of qualitative case study and quantitative survey methods, have been made (Shield, 1997; Ittner e Larcker, 2001). In this study, we used a mixed approach, which is generally advised in this research area (Sutton, 2000). The focus was on empirical research, defined as "research that uses qualitative or quantitative data as a basis for the investigation of research questions" (Benbasat \& Nault, 1990:211). For the collection of data, a number of methods were evaluated, e.g. experiments, surveys and case studies (Ryan et al., 2002). Based on the purpose of our study and to successfully deal with the challenges indentified in the literature review this study will require the researcher to invest in and conduct more integrative research (Shields, 1997). Consequently this study will use a combination of qualitative and quantitative data to address the research question posed: - Will the development of IT have changed the organisation of accounting tasks?

Following a multiple case design, this phase of our study consisted of face-to-face interviews in six manufacturing firms (see table 1). In methodological terms, we considered 
six to be a sufficient number of case studies (Luoma, 1967; Yin, 2003; Hamilton \& Asundi, 2008). Case research has been advocated as a valid research strategy in management information systems (Benbasat et al., 1987) but less in the accounting field (Dul \& Hak, 2008). However, case study research in managerial accounting is more popular than in other accounting area (Cooper \& Morgan, 2008).

Usually, "the decision to use a case study approach is a strategic decision that relates to the scale and scope of an investigation..." (Denscombe, 2003:32). Our research question requires a comparative analysis between pre- and post-"new technologies" to describe the manager's attitude towards their availability. And, qualitative analysis focused on case studies, given their application in situations in which the intervention should be described in a real context (Yin, 2003; Cooper \& Morgan, 2008). "This close involvement with the organisation means that interviews and direct observations of activities tend to be the primary means of data collection in case research" (Doolin, 1996:23). To achieve our purpose during the interviews we try to collect the main accounting documents used in decision-making. Due to "document can be treated as a source of data in their own right" (Denscombe, 2003:212), we used them to triangulate documents content with interviews. So our primary sources of data were interviews and analysis of documents providing details of the project and its outcomes; we used the documents to corroborate, and clarify the data collected through interviews. A total of 34 hours of interviews was conducted on site during 3 months. All interviews were tape recorded and transcribed.

\section{MAIN RESULTS}

In the literature, some criticism traditionally raised against accounting point to (1) the excessive perfectionism on the part of accountants, which makes it difficult to obtain and understand information in a timely fashion; (2) excessive data schemes which make it difficult to understand; (3) conceptual divergence between accountants and other managers - accountants pay too much attention to formal aspects, neglecting a more dynamic accounting that would be more appropriate to the manager needs; (4) the lack of interest of other managers regarding accounting services which they see as a mere fiscal and legal condition. Given these criticisms, managers tend to try to construct their own accounting documentation, which they understand better and obtain more rapidly although it is more imprecise (Vilaine, 1970).

In the case studies, a lot of accounting documents used by marketing managers and operating managers are produced in the accounting department (see tables 2 and 3) However, in production, most of these documents are produced locally. So, the data gathered demonstrated that many of the most used documents with accounting information in the areas studied are produced locally, almost always with computer support, for operating managers. In some cases, this tendency for managers to try to construct their own documentation led to divergence between their documents and those from the accounting department. This is not a new situation and should be considered (Vilaine, 1970).

Analysing the purpose of using these documents, accounting documents served primarily to make projections and to define corrective action and, similarly to what was found in Simon's study (Simon et al., 1954), they are more frequently used to "understand the current state of the company" and to "identify problems" than to "solve problems". Likewise, some documents were found to be elaborated because feedback should be well-established so that all the collaborators can exercise self-control by comparing expectations with results (Drucker, 1992). Nevertheless, documents elaborated for this purpose do not always fulfil their objective.

Just as in Burns' study (Burns et al., 1999) this study found a decentralisation of tasks traditionally centralised in accounting, such as the creation of budgets.

\section{CONCLUSIONS}

The companies studied have high levels of investment in information technology. The area of sales/marketing was found to use laptops more significantly than the other areas due to the nature of their activities, notably the greater need to work beyond the confines of the company.

The data gathered demonstrate that many of the documents with accounting information used in the areas studied are produced locally, almost always with computer support. Analysing the purpose of the use of these documents, we found that, regardless of their origin, the accounting documents used basically serve to make projections and to define corrective actions and, similarly to what was found in Simon's study (Simon et al., 1954), they are more frequently used to "understand the current state of the company" and to "identify problems" than to "solve problems". Lastly, this study found a decentralisation of tasks traditionally centralised in accounting department.

Future research needs to examine the IT / accounting relationship. Today accounting and IT are inseparable. Accountant's uses of sophisticated management accounting techniques are clearly dependent of IT existence. The configuration choices made in IT implementation are powerful in what enable. The benefits for accounting from IT materialise only in uncertain ways and only after long implementations.

\section{ACKNOWLEDGEMENTS}

The author would like to thank the financial support from Portuguese Foundation for Science and Technology (FCT Programa de Financiamento Plurianual das Unidades de I\&D). Research Unit: NECE - Núcleo de Estudos em Ciências Empresariais, University of Beira Interior, Portugal.

\section{REFERENCES}

[1] Benbasat I. \& Nault B. An Evaluation of Empirical Research in Managerial Support Systems. Decision Support Systems. 1990, 6, August: 203-226.

[2] Benbasat I., Goldstein D. \& Mead M. The Case research Strategy in Studies of Information Systems. MIS Quarterl. 1987, September: 369-386.

[3] Burns, J., Ezzamel, M. \& Scapens, R. Management accounting change in the UK. Management Accounting. 1999, 77 (3): 28-30. 
[4] Chien S. \& Tsaur S. Investigating the success of ERP systems: Case studies in three Taiwanese high-tech industries. Computer in Industry. 2007, 58:783-793.

[5] Chua W. Radical Developments in Accounting Thought. The Accounting Review. 1986, LVI (4):601-632.

[6] Connor N. \& Martinsons M. Management of information systems: Insights from accounting research. Informations \& Management, 2006 , 43:1014-1024.

[7] Cooper D. \& Morgan W. Case Study Research in Accounting. Accounting Horizons. 2008, 22 (2):159-178.

[8] Crescenzi A.D. \& Kocher J. Management Support Systems: opportunity for Controllers. Management Accounting. 1984, 65(9):34-36.

[9] Dechow N., Granlund M. \& Mouritsen J. Management Control of the Complex Organization: Relationships between Management Accounting \& Information Technology. In: C. Chapman, et al (eds). Handbook of Management Accounting Research. Elservier, Lda. 2007:625-640.

[10] Dedrick J., Gurbaxani V. \& Kraemer K. Information technology and economic performance: A critical review of the empirical evidence. ACM Computing Surveys. 2003, 34 (1):1-28.

[11] Dehning B. \& Richardson V. Returns on Investments in Information Technology: A Research Synthesis. Journal of Information Systems. 2002, $16(1): 7-30$.

[12] Denscombe M. The Good Research Guide - for Small Social Research Projects. $2^{\mathrm{a}}$ Ed., Open University Press, McGraw-Hill Education, 2003.

[13] Doolin B. "Alternative views of case research in information systems. Australian Journal of Information Systems. 1996, 3 (2):21-29.

[14] Drucker, P., F. Managing for the Future. Translation from English by F. Velez, Difusão Cultural, Lisbon. 1992.

[15] Dul J. \& Hak T. Case Study Methodology in Business Research. Elservier Ltd. 2008.

[16] Edmunds A. \& Morris A. The problem of information overload in business organizations: a review of the literature. International Journal of Information Management. 2000, 20:17-28.

[17] Efendi J., Mulig E. \& Smith L. Information Technology and Systems Research Published in Major accounting Academic and Professional Journals. Journal of Emerging Technologies in Accounting. 2006, 3:117-128.

[18] Frishamar, J. Characteristics in information processing approaches. International Journal of Information Management. 2002, 22:143-156.

[19] Granlund M. \& Mouritsen J. Introduction: problematizing the relationship between management control and information technology. European Accounting Review. 2003, 2 (1):77-83.

[20] Granlund M. On the Interface Between Management Accounting and Modern Information Technology - A literature review and some empirical evidence. Working paper, SSRN, http://ssrn.com/abstract=985074. 2007.

[21] Hamilton, L. C. \& Asundi, R. Technology usage and innovation - its effects on the profitability of SMEs. Management research News. 2008, 31(11):830-845.

[22] Hopper T. \& Powell A. Making sense of research into the organizational and social aspects of management accounting: a review of its underlying assumptions. Journal of Management Studies. 1985, 22 (5):429- 465.

[23] Hopwood A. The archaeology of accounting systems. Accounting, Organizations and Society. 1987, 11:207-234.

[24] Huang S., Ou C., Chen C. \& Lin B. An empirical study of relationship between IT investment and firm performance: A resource-based perspective. European Journal of Operational Research. 2006 173:984-999.

[25] Hunton, J. E. Blending Information and Communication Technology with Accounting Research. Accounting Horizons. 2002, 16(1):55-67.

[26] Ittner C. \& Larcker D. Assessing empirical research in managerial accounting: a value-based management perspective. Journal of Accounting \& Economics. 2001, 32:349-410.

[27] Johnson, D.G., King M., Lee R.A. \& Piper J.A. Studying the impact of information technology on the role of the management accountant - A conceptual framework and research method. Management Research News. 1986, 9(4):4-6. Article URL: http://www.emeraldinsight.com/10.1108/eb027891

[28] Luoma G. Accounting Information in Managerial Decision-Making for Small \& Medium Manufacturers. Research Monograph $\mathrm{n}^{\mathrm{o}} 2$, National Association of Accountants, New York, USA. 1967.

[29] McLeod R., Jones J. \& Poitevent J. Executives' perceptions of their information sources. Reprint in Gray P. Decision Support \& Executive Information Systems. Prentice Hall, 1984:108-122.

[30] Melville N., Kraemer K \& Gurbaxani V. Review: information technology and organizational performance: An integrative model of IT business value. MIS Quarterly. 2004, 28 (2):283-322.

[31] Modell S. Triangulation between case study and survey methods in management accounting research: An assessment of validity implications. Management Accounting Research. 2005, 16: 231-254.

[32] Rom A. \& Rohde C. Management accounting and integrated information systems: A literature review. International Journal of Accounting Information Systems. 2007, 18:40-68.

[33] Ryan B., Scapens R. \& Theobald M. Research Method and Methodology in Finance and Accounting. 2nd ed. London, UK: Thomson. 2002.

[34] Shields M. Research in Management Accounting by North Americans in the 1990s. Journal of Management Accounting Research. 1997, 9:3-61.

[35] Simon A., Guetzkow H., Kozmetsky G. \& Tyndall G. Centralization Vs. Decentralization in Organizing the Controller's Department. A Research Study \& Report prepared for Controllership Foundation, New York.1954.

[36] Simon H. Administrative Behavior - A Study of Decision-Making Processes in Administrative Organizations. 4th ed, 1997, The Free Press, London. 1945.

[37] Stoel, M. D. \& Muhanna W. A. IT capabilities and firm performance: A contingency analysis of the role of industry and IT capability type. Information \& Management. 2009, 46:181-189.

[38] Sutton S. G. The Changing face of Accounting in an Information Technology dominated World. International Journal of Accounting Information Systems. 2000, 1:1-8.

[39] Teng J. \& Calhoun K. Organizational Computing as a Facilitator of Operational and Managerial Decision Making: an Exploratory Study of managers' Perceptions. Decision Sciences. Fall 1996:673-710.

[40] Vilaine, B. Comptabilité et Informatique. Dunod, Paris. 1970.

[41] Yin R. Case Study Research - Design \& methods. Applied Social Research Methods Series. Vol. 5, $3^{\mathrm{a}}$ Ed. CA: Sage, Thousand Oaks. 2003.

[42] Yongmei L., Hongjian L. \& Junhua H. IT Capability as moderator between IT investment and firm performance. Tsinghua Science and Technology. 2008, 13(3):329-336.

TABLE 1 - INTERVIEWS

\begin{tabular}{cccc}
\hline \multirow{2}{*}{$\begin{array}{c}\text { Case } \\
\text { Study }\end{array}$} & \multicolumn{3}{c}{ Number of interviews / functional area } \\
\cline { 2 - 4 } & Finance/Accounting & Sales/Marketing & Production \\
\hline 1 & 2 & 1 & 2 \\
\hline 2 & 1 & 0 & 1 \\
\hline 3 & 1 & 1 & 1 \\
\hline 4 & 1 & 1 & 1 \\
\hline 5 & 1 & 0 & 1 \\
\hline 6 & 1 & 0 & 1 \\
\hline TOTAL & 7 & 3 & 3 \\
\hline
\end{tabular}


TABLE 2 - ACCOUNTING DOCUMENTS USED BY MARKETING MANAGERS

\begin{tabular}{ccc}
\hline Document & From: & Is this document produced locally? \\
\hline CASE STUDY 1 & & No \\
\hline Ledger list & Accounting information System & Yes \\
\hline Activities report - Strategic Business Unit & Controller & Yes \\
\hline Annual Activities report & Controller & Yes \\
\hline Business Plan & Controller & \\
\hline CASE STUDY 3 & & No \\
\hline Customer profitability analysis & Accounting information System & \\
\hline Revenue by selling group & Accounting information System & No \\
\hline Sales journal & Accounting information System & No \\
\hline Budgets from firms outsourced & Outsourcing & Yes \\
\hline Internal Budget & Manager & No \\
\hline & & No \\
\hline CASE STUDY 4 & Accounting department & No \\
\hline Internal market Sales analysis & Accounting department & No \\
\hline Internal market Sales- by selling group & Accounting department & No \\
\hline Sales analysis by market and product & Accounting department & No \\
\hline Sales/cost analysis/Definition of the selling price. & Accounting department & \\
\hline Sales analysis - by market & Finished goods inventory manager & \\
\hline External Failure Costs & &
\end{tabular}

TABLE 3 - ACCOUNTING DOCUMENTS USED BY OPERATING MANAGERS

\begin{tabular}{|c|c|c|}
\hline Document & From & Is this document produced locally? \\
\hline \multicolumn{3}{|l|}{ CASE STUDY 1} \\
\hline $\begin{array}{c}\text { Suppliers' Journal } \\
\end{array}$ & Accounting department & No \\
\hline Order entry & Purchase manager & Yes \\
\hline Job Order Costing & Controller & Yes \\
\hline Job Order Cost Sheet & Controller & Yes \\
\hline Customer Budget Report & Accounting department & No \\
\hline \multicolumn{3}{|l|}{ CASE STUDY 1} \\
\hline Ledger list & Accounting information System & No \\
\hline Job Order Costing & Accounting information System & No \\
\hline Payroll Report & Controller & Yes \\
\hline Sales Journal & Accounting information System & No \\
\hline Internal report of activities & Controller & Yes \\
\hline Business Plan - Strategic Business Unit & Controller & Yes \\
\hline \multicolumn{3}{|l|}{ CASE STUDY 2} \\
\hline Profit and Loss Statement & Financial department & No \\
\hline Annual Budget Analysis & Financial department & No \\
\hline Summary - Balance sheet and Income Statement & Financial department & No \\
\hline Cost Control Variance & Accounting department & No \\
\hline Production Costs Reports & Controller & Yes \\
\hline Investment appraisal & Controller & Yes \\
\hline \multicolumn{3}{|l|}{ CASE STUDY 3} \\
\hline Income Summary & Accounting department & No \\
\hline Industry Ratios & Quality manager & Yes \\
\hline Production forecasts & Forecasting sector & Yes \\
\hline \multicolumn{3}{|l|}{ CASE STUDY 4} \\
\hline Inventory Status File & Finished goods inventory manager & Yes \\
\hline Job order costing & Commercial Department & No \\
\hline Contract Auditing & Commercial Department & No \\
\hline Bill of Materials & Department staff & Yes \\
\hline \multicolumn{3}{|l|}{ CASE STUDY 5} \\
\hline Job order costing & Department staff & Yes \\
\hline Equipment usage reports & Department staff & Yes \\
\hline Order Budget & Department staff & Yes \\
\hline \multicolumn{3}{|l|}{ CASE STUDY 6} \\
\hline Balance Sheet & Accounting department & No \\
\hline Income Statement & Accounting department & No \\
\hline Production Cost report by product & Accounting department & No \\
\hline CVP analysis & Department staff & Yes \\
\hline Labor payroll Report & Department staff & Yes \\
\hline Variance analysis Report & Department staff & Yes \\
\hline Gross Margin and cost allocation by product & Accounting department & No \\
\hline
\end{tabular}

